対駱暖流に抢けるる邻水瑰の衛星りモート七ンシング

$\begin{array}{lrl}\text { 長崎大学大学院海洋生産科学研究科 } & \text { 学生員 } & \text { 湯藤 義文 } \\ \text { 同上工学部 } & \text { 正会員 } & \text { 後藤恵之輔 } \\ \text { 九州大学応用力学研究所 } & & \text { 川建 和雄 } \\ \text { 福岡県福岡水産試験場 } & & \text { 三井田恒博 }\end{array}$

\title{
1.まえがき
}

日本海の海流で最も顕著な海流は、対馬暖流であり、黒潮からの分岐流である。九州西南沖合で黒潮主流から 分離した暖流は九州西方を北上し、五島列島西沖から対馬海峡を経て日本海へ流れ込む。九州大学灾用力学研究

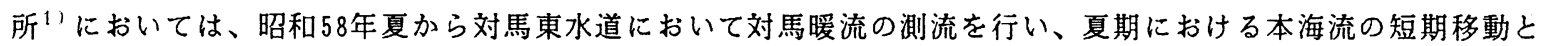
冷水域の存在を明らかにしている。しかし、この測流は定点観測によっているため、黒潮に比べて、流量、流速 とあ小さく、変化が大きい対馬暖流においては、観測点における海中の鉛直情報は得られるすのの、広域にわた る立体情報を詳細に把握することはきわめて難しい。

衛星りモートセンシングによるデー夕解析は、精度等の問題はあるが、反復広域観測が可能であるので、変化 しやすい対馬暖流域の観測に適していると考えられる。

そこで本研究では、人工衛星データを用いて、対馬東水道及び周辺海域の海面温度分布を求め、対馬暖流にお ける冷水塊の存在をさらに解明するすのである。衛星データには極軌道気象衛星N O A A A V H R R (改良型 超高分解能放射計）データを使用し、観測日は定点観測が行われた期間に合わせた昭和60年 7月15日と、他の時期 として春期である昭和 61 年3月6日、昭和63年4月14日とする。

\section{2. 冷水塊の探查目的}

冷水塊の探查を行う必要性の背景としては、2つのことがある。1つは冷水塊が水産業に大きな影響を与える ことにある。その例として、4 年前の九州南東海における黒潮の蛇行現象 ${ }^{2}$ である。こ机は図一 1 に示すように、 発生した冷水域によって、黒潮が大きく南方へ蛇行したもので、この蛇行現象のために、南九州の漁業に大きく 影響した。特にイワシやスルメイカの漁獲減少が起こった。また他の例として、暚岐海領における海中の密度成 層面に発生する内部波現象 ${ }^{3)}$-4)である。これは、対馬暖流が潮汐流と合成されることによって、迂回する流速は 変化を起こし、日本海固有冷水が $30 \mathrm{~m}$ 位上がったり下がったりする現象が起こり、図一2のように冷水塊が陸棚 へ打ち上げられる。これにより、タイ等の底層魚が内部波のフロントに追われる現象など、行動に影響を与える ようである。そうすると夕イ等の漁場は、このような陸棚の上部が良いことになる。これらのことから、冷水塊 の存在を確認することによって、適切な漁場を判断あるいは示唆することが出来るすのと考えられる。

むう 1 つの背景としては、海洋温度差発電（ＯT E C)の設置場所を判断することにある。海洋温度差発電とは、 海水の表層部と深層部との温度差を利用して、電気エネルギーを得るシステム ${ }^{5}$ で、図ー 3 にその原理を示す。 これは、蒸発器の中に低温で蒸発する物質を入れておき、この物質を温かい表層水で加熱して、液体は蒸気にな る。この蒸気によってタービンを回転させ、さらに蒸気は凝縮器に入り、冷たい底層水によって液体に戻る。

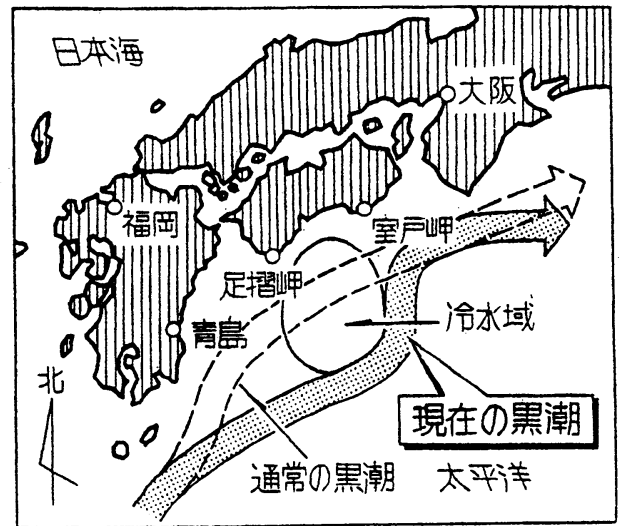

図-1 黒潮の蛇行現象 2

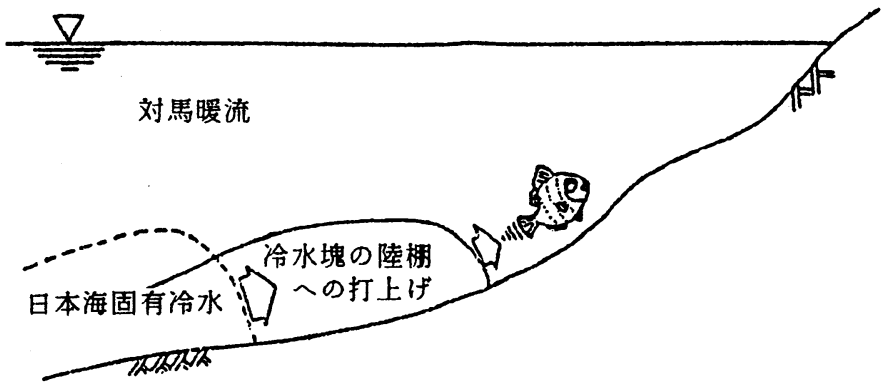

図-2 内部成首面の波動 ${ }^{4}$ 
これを繰り返し行う。しかし海洋温度差発電は、温水と 冷水の温度差が $20^{\circ} \mathrm{C}$ 以上必要であるため、日本近海では、 無理であると言われている。そのため、冷水塊の存在を 確認することによって、この海洋温度差発電が少しです 可能な海域を発見することが出来るのではないかと考え られる。

\section{3. 解析の準傮}

\section{1 解析対象海域的}

解析は図一 4 に示すように対馬東水道の最強流域（対 馬一壱岐間）を含む海域を対象とした。図中のの印は昭 和58年度に実施した定位置測流点 $\left(\mathrm{T}_{1}, \mathrm{~T}_{2}, \cdots \mathrm{T}_{5}\right)$ を示す。観測期間は昭和60年度の場合、7月8日から9月3日 までの58年日間である。

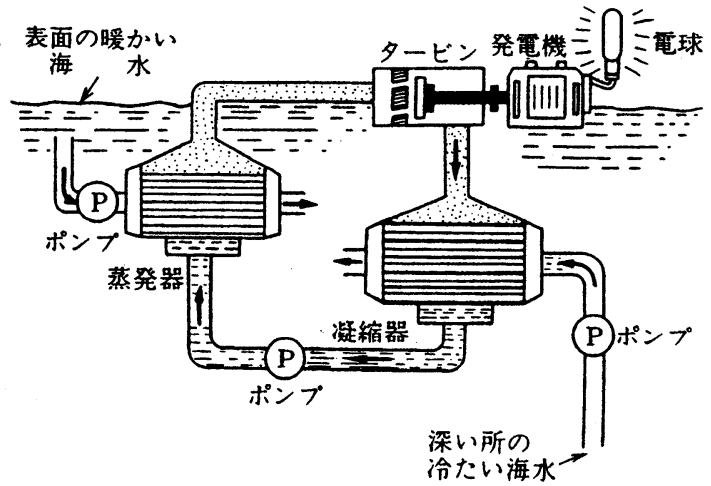

図一 3 海洋温度差発電の原理 ${ }^{51}$

図一 4 の測線 $\mathrm{A}$ と B は、流速計の設置航海時において水温と塩分の鉊直断面分布を計測したラインであり、測 点間隔は $4.8 \mathrm{~km} て ゙$ る。一例として、図一 5 に測線 B における水温の鉊直断面図を示す(ただし、この図は昭和58年 7月28日観測のもの)。

この図によれば、水温 $15^{\circ} \mathrm{C}$ 程度の冷水域は夏期の初めごろに生じやすいが、その理由は九州側の水深が浅いた め加熱期に入ると急速に昇温するからである。

\section{2 探查のための手法}

本研究の探査方法は、人工衛星のデータを用いて解析するすのであるが、このデータだけでは、水温の海面温 度しか判断できない。

そこで、このデータを用いて冷水塊の存在を知るためには、次のことが考えられる。ここで図一 5 を見てみる と、対馬寄りの海面温度が低いことが分かる。これは、この海域では底層水が循環流のような流れにより、湧昇 現象の様なことが起こり、対馬東水道の最深部（深さ $100 \mathrm{~m}$ 前後）における水温 $15^{\circ} \mathrm{C}$ 程度の冷水が、上昇するので はないかと思われる。図－5でも分かるように、いわゆる「水温の押し上げ現象」によって、このような海面温 度差が出来るむのと考えられる。故に、人工衛星で海面温度を探查することによって、冷水塊の存在を確認でき ることになる。

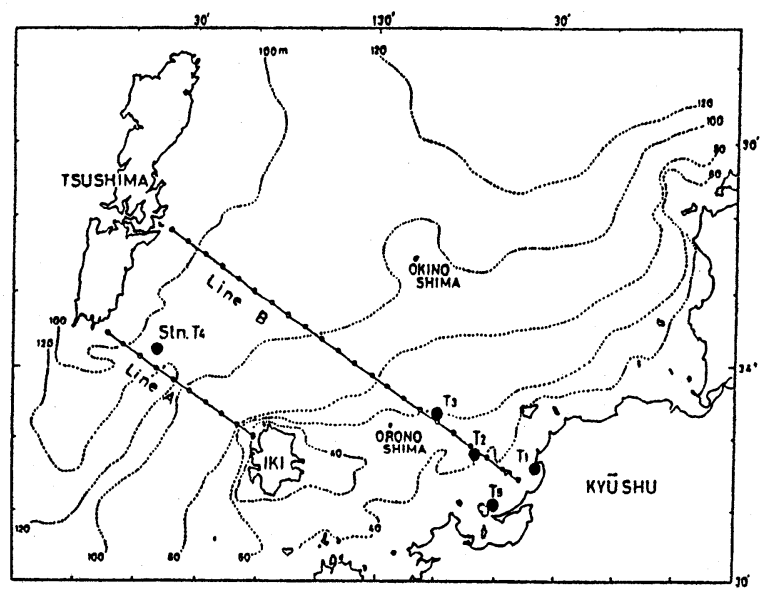

図-4 対象海域

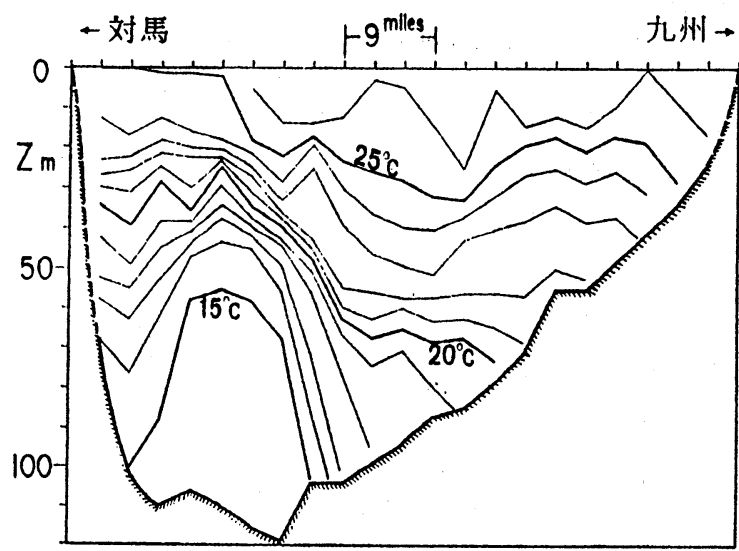

図 -5 水温鉊直断面図 (昭和58年7月 28日 $)^{1)}$

\section{4. 衛星データの概要}

4.1 NOA A 解星

現在運用されているNOA A シリーズの衛星は、米国で極軌道衛星として開発された、第 3 世代の気象衛星で ある。その目的は、静止気象衛星之相補い、気象予報・警報、海洋・水理業務、宇宙観測に改良された資料を提 供することにある。1978年10月に T I R O S - N が打ち上げられて以来、NOA A 6，7，8号が次々と打ち上 げられ、現在は、1984年8月に打ち上げられた 9 号が稼働中である。

このシリーズは、常時 2 個の衛星により観測が行われることになっており、太陽同期で互いに逆方向にしかむ 互いに直角の軌道面を保ちつつ円形軌道をまわっている。 


\section{2 使用データ}

T I ROS - N/NOAAシリーズに搭載しているミッション機器のうち、本解析では、A V H R R のデータ を利用する。使用したデータは昭和60年7月15日午後2時28分（日本時間）、昭和61年3月6日午前 5 時47分（同）と 昭和 63 年 4 月 14 日午後 10 時55分（同）、いずれもNOAA 9 号により観測されたものである。AVHR R は従来の NOA A シリーズに搭載された高分解能放射計(V H R R )の改良型で、表ー 2 に示すように可視・赤外波長域に 5 チャンネルの観測波長帯域をすつ。

この中で、チャンネル1（可視）においては、雲、水、雪等の識別に使うことができる。チャンネル2（近赤 外）は、海岸線、雪、水、結水・解水の識別に役立つ。チャンネル3（中間赤外）は従来の赤外バンドに近いる ので、海面及び陸、雲等の温度の測定に用いられる。チャンネル4（熱赤外）は、第 2 の大気の空といわれるチ ャンネルであり、チャンネル 3 と同じ用途の測定に用いられるが、昼夜共に観測が可能である。チャンネル5（熱 赤外）は、チャンネル 4 と同じ海面温度の測定に用いられる。いずれのチャンネルにおいてす、分解能は $1.1 \mathrm{~km}$ ある(1).71。

A V H R Rで测定されたデータは、衛星に搭載されているデータ処理装置（M I R P ）によって、高解像度画 像伝送（H R P T) の信号が作られる。H P T データは、1698M H Zと1707M H Zで360本／分の標準ファクシ ミリにより位相変調のディジタル信号として地上局に送信される。データの読み出しは、地上受信局上空で指命 により高速で行われるが、H R P T のデータは軌道一周分を記録できないので必要な地域のみとなっている。

表一 1 NOA A - 9 / A V H R R 観測波長帯域 ${ }^{(j)}$

\begin{tabular}{|c|c|c|}
\hline チャンネル & \multicolumn{2}{|c|}{ 観測波長帯域 $(\mu \mathrm{m})$} \\
\hline 1 & $0.58 \sim 0.68$ & 可 視 光 \\
\hline 2 & $0.725 \sim 1.10$ & 近 赤 外 \\
\hline 3 & $3.55 \sim 3.39$ & 中 間 赤 外 \\
\hline 4 & $10.5 \sim 11.3$ & 熱 赤 外 \\
\hline 5 & $11.5 \sim 12.5$ & \\
\hline
\end{tabular}

4. 3 海面温度の計算

本研究では、以上の 5 チャンネルのうち、夜間データも使えるチャンネル 4 の熱赤外データを用いて、海面温 度を計算する。データは磁気テープ中に0〜255の範囲の数值（C C T 值という）として入っており、海面温度は この C C T 值から直接求めることができる。

しかし、この C C T 值よりそのまま海面温度の計算を行うと、実際の水温より低めに求められ、その誤差も一 定でない。その原因は、海水のもつ物理温度と見掛けの輝度温度との間に差のあること、また大気を通過する間 に大気中の水蒸気などの吸収媒体によって放射輝度エネルギーが減衰されることによるの。しかし、本研究では 海面温度の相対的分布を見るため、絶対值をそれほど必要としないことから、このような大気効果の補正は行わ ず、A V H R R データによる C C T 值をそのまま海面温度として扱うこととする。

\section{5. 解析結果}

5. 1 温度分布

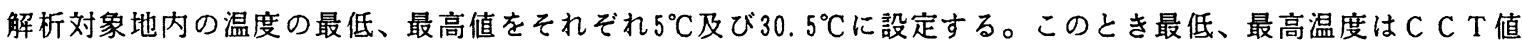

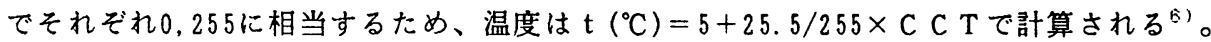

因ー6に示すのは、温度を10段階に分け各レ゙゙ルを記号て表したヴレイマップてある。C C T 值に対する各レ ベルの割り当てについて、夏期に当たる昭和60年7月15日のデータに対して相対的に低温な昭和61年3月6日と昭和 63年4月14日のデータについては、あまり海面温度の差がないため、割り当ての範囲を細かくした。これらの図で は、地形を明らかにするため、範囲を解析対象地だけでなく、南は長崎、熊本まで含んでいる。また、各記号は、 ひずみが補正された $3 \mathrm{~km}$ 平方の大きさである。以下に各データの温度分布を述べる。

昭和60年7月15日データ(図一 $6(\mathrm{a})$ )

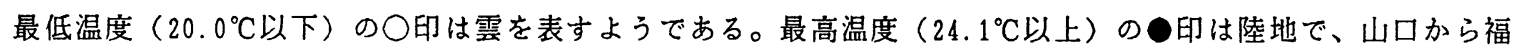
岡、佐賀、熊本にかけての内陸部は大半雲に覆われ、対馬の一部にす雲のあることが分かる。

昭和61年3月6日デー夕(図-6(b))

各レベルは、図ー4の海域における海面温度の割り当てを考えて、このような形とした。それ故、南方におけ る高温域については、陸地と対馬暖流の温度が共に最高温度（16.0² $\mathrm{C}$ 上）の○印となっている。また、北方沖 の○印で示す最低温度（15.1 ${ }^{\circ} \mathrm{C}$ 以下）は、雲を表す。 

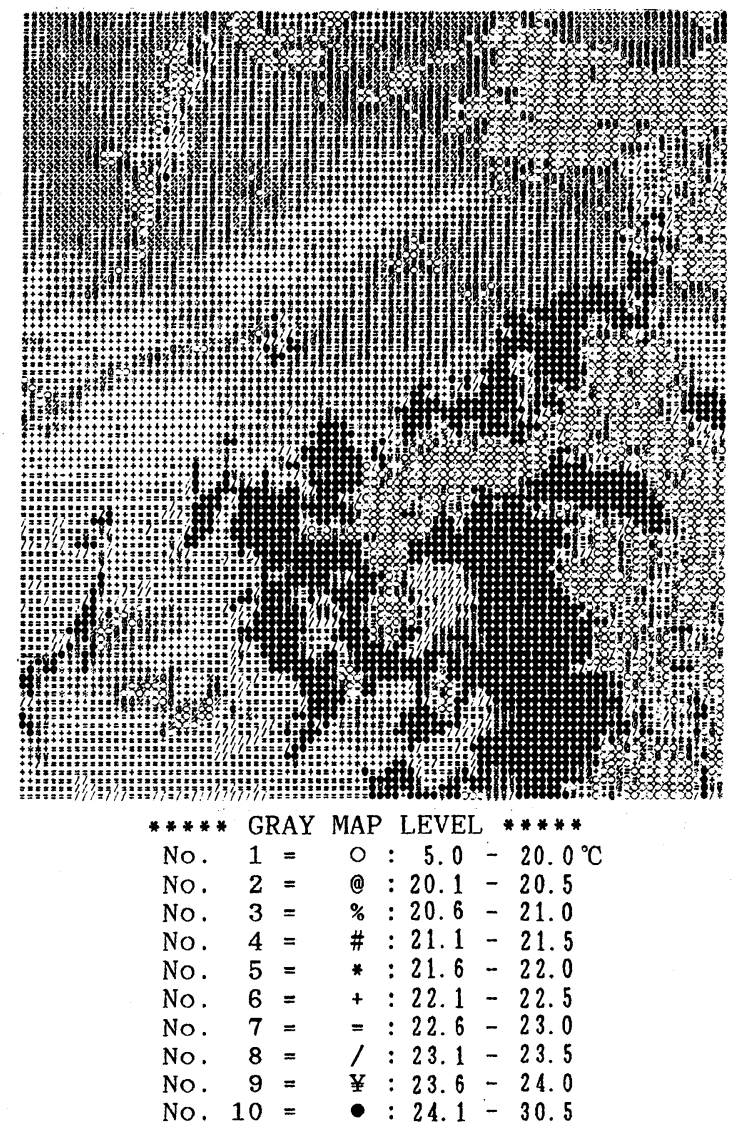

(a) 昭和60年7月15日
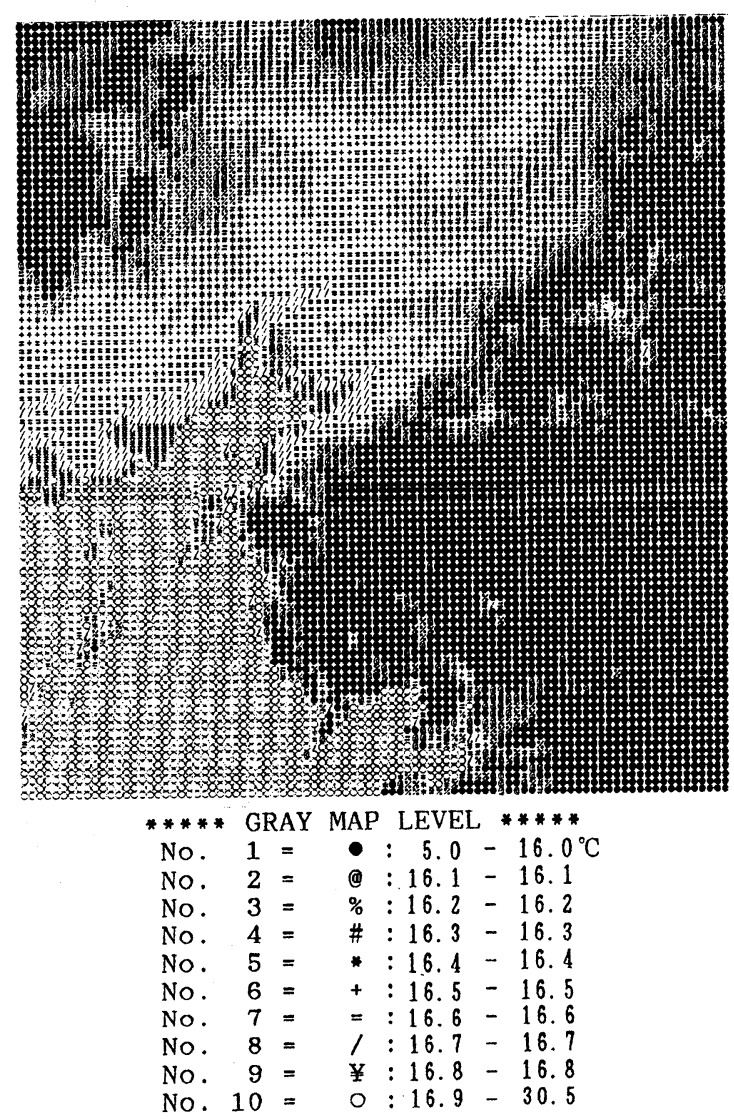

(c) 昭和 63 年 4 月 14 日

図-6 温度分布図

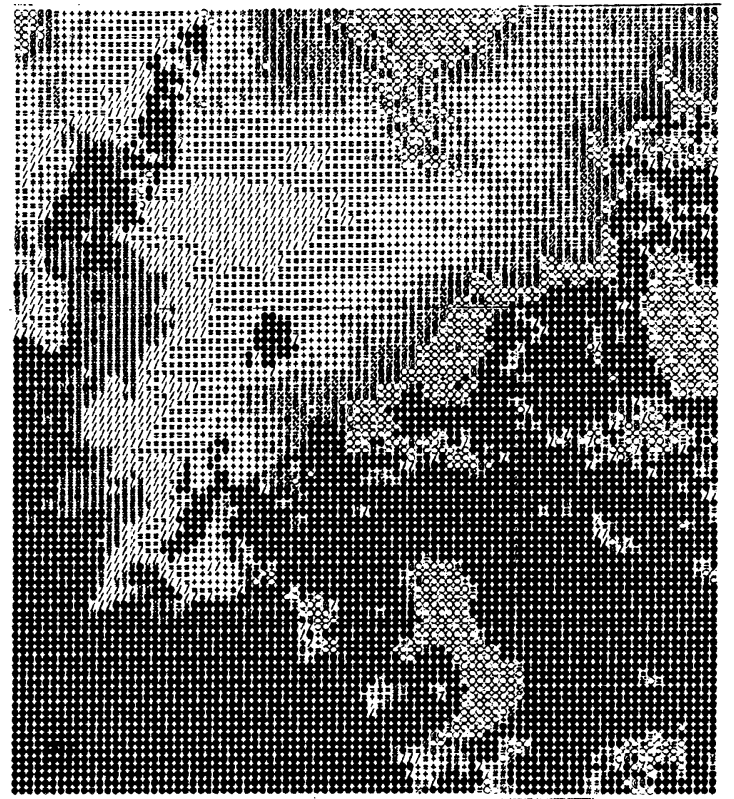

***** GRAY MAP LEVEL *****

No. $\quad 1=0: 5.0-15.1^{\circ} \mathrm{C}$

No. $3=\%: 15.3-15.3$

No. $4=\#: 15.4-15.4$

No. $5=*: 15.5-15.5$

No. $6=+: 15.6 .-15.6$

No. $7=\quad=: 15.7-15.7$

No. $8=/: 15.8-15.8$

No. $10=:$ : $16.0-30.5$

(b) 昭和 61 年 3 月 6 日 
昭和63年4月14日デー夕(図-6(c))

最低，最高温度の記号（のと○）が他のデータと逆になっているのは、陸地を分かりやすくするためである。 南方では、陸地と対馬暖流との温度差がはっきりしていることが分かる。また、他のデータとは逆に、陸地より 海面の温度の方が高いことも分かる。

\section{2 海面温度}

図-7 は図-6 の温度分布図から作成した海面温度のコンター図である。図中の数值は温度 ( $\left.{ }^{\circ} \mathrm{C}\right)$ を表す。両 図から、どの観測日も海面温度は南の方が北より高く、その温度の高い海流（対馬暖流）が、対馬と九州に挟ま れた対馬東水道に流入していく様子が分かる。

ここで、図ー7を図ー4 の測線 Bについて見てみる。まず、図ー 4 に示す観測日と同じ時期に当たる昭和 60 年 7月15日のデータから見ることにする。対馬寄りの海域に周囲より温度の低い箇所のあることが分かる。これは、

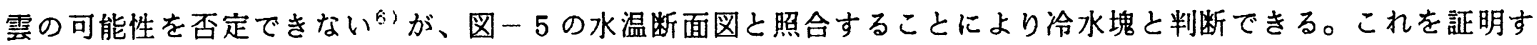
るため、測線 $\mathrm{B}$ 上の温度分布を図ー 8 に示す。さらに図ー 8 を図一 5 と対比することによって、両図とす対馬側

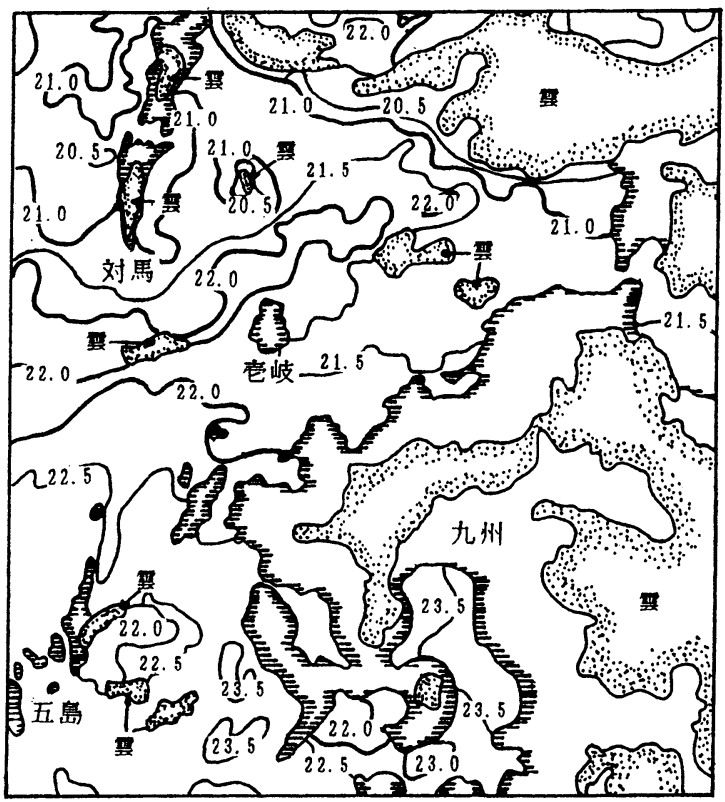

(a) 昭和 60 年7月 15 日

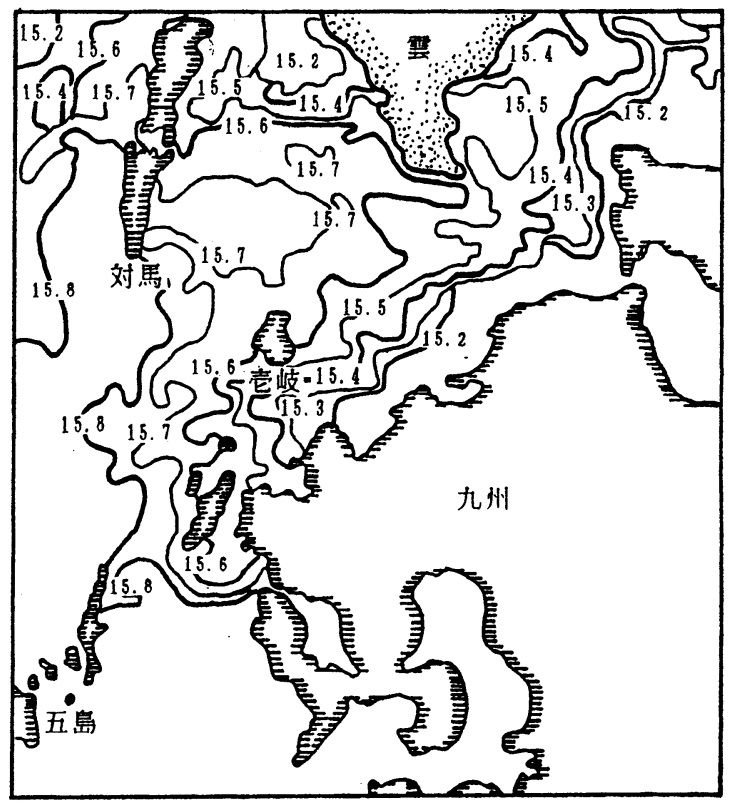

(b) 昭和 61 年 3 月 6 日

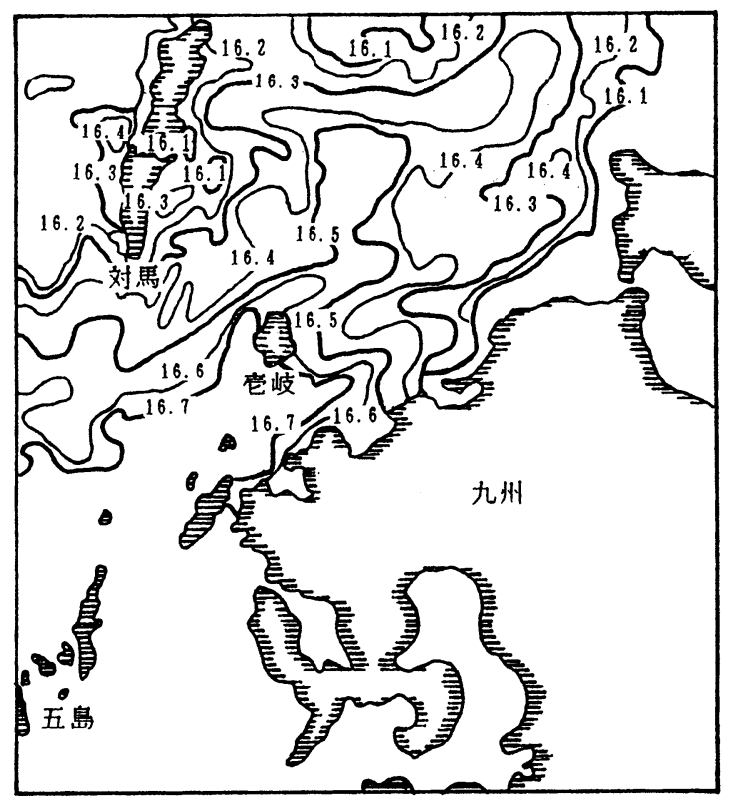

(c) 昭和 63 年 4 月 14 日

図- 7 海面温度図 


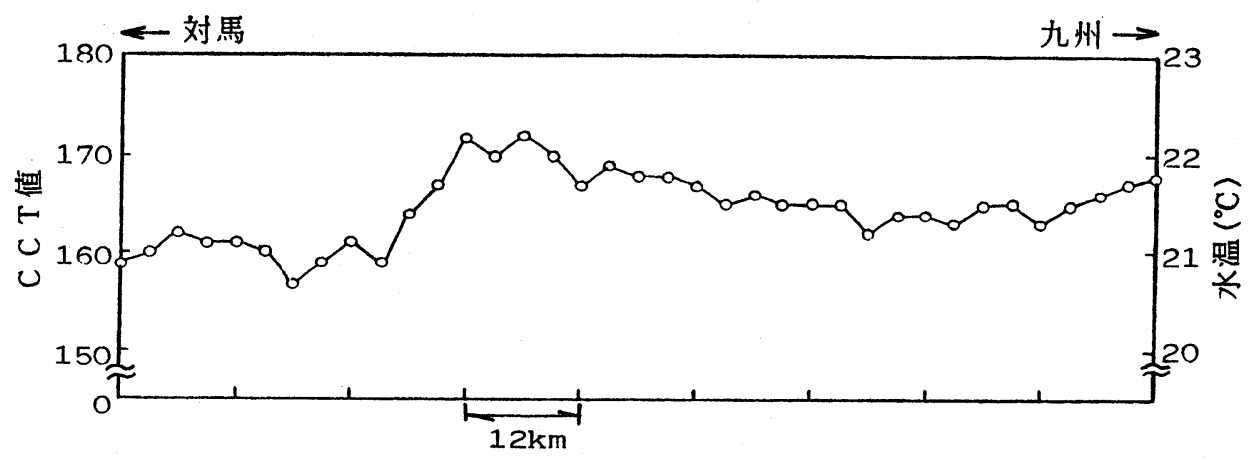

図一8 測線 B における海面温度分布図(昭和60年7月15日)

で温度が低くなっていることが分かり、以上より、冷水塊の存在を認めることができる。ただし、図一 5 は昭和 58 年7月 28日、図-8は昭和60年7月15日の観測であり、観測日の相違に注意しなければならない。

さらにこの冷水塊周辺について、昭和61年3月6日と昭和 63 年 4 月 14 日の両デー夕からす見てみる。

時期的な暖流の流軸のふれや蛇行性などの変化により、多少冷水塊の場所のずれは考えられるすのの、図ー7

(c)の 4 月のデータからす、対馬寄りの海域に冷水塊が存在していることが分かる。

しかし、図-7（b)の 3 月のデータからは、この水域周辺における冷水塊の存在ははっきりしない。

この結果、この海域 (対馬東水道)では、夏期の暖水期において顕著に冷水塊を発見できるのに対して、春期に

おいては、この海域での最高と最低の温度差があまり大きくないために、冷水塊を発見することは難しい。

故に、人工衛星データを用いて冷水塊の存在を解明するためには、水温が低い時期よりす、水温が高い特に夏 期のデータを用いるのがよいと考えられる。

6. あとがき

解析を行った NOA Aデータのうち、特に夏期のデータ（昭和60年7月15日）功、実測結果と合致する冷水塊 の存在が認められた。また、冷水塊の存在を解明するには、この海域においては、海面の温度差が大きい夏期の データを用いる方がよいことが分かった。

しかし、今回解析に用いたデー夕は、あくまでも夏期と春期のデータだけであるために、冬期や秋期のデー夕 についても解析することによって、さらに新しい結果が生まれるのではないかと思われる。今後の研究課題にし ていきたいと思う。また、今回は図ー4の測線 B について重点的に解析を行ったが、今後さらに範囲を広げて解 析を行う必要がある。

今回使用した人工衛星データは、NOA A / A V H R R ゙゙ータであるが、それ以外に海面温度を把握できる人 工衛星には、現在L A N D S A T / T M ンサーや、我が国初の海洋観測衛星MOSー1／V T I R センサーな どがある。NOAA/A V H R R ゙゙ータは、分解能がL A D S A T / T Mデータよりかなり劣るが（分解能 $\mathrm{A} \mathrm{V} \mathrm{H} \mathrm{R} \mathrm{R}=1.1 \mathrm{~km}, T \mathrm{M}=120 \mathrm{~m}$ )、同一地域を 1 日に 2 回観測し、状況変化の激しい海洋の観測に適している。 お互いに一長一短はあるが、NOA A と L A N D S A T 、MOS - 1 を併用することにより、さらに人工衛星デ 一タによる海洋観測における信頼性が增すであろう。

N O A A の問題点は、A V H R R データから計算される海面温度が、大気効果のため実際より低目であること にある。本研究においてる、この大気効果を補正することなくチャンネル 4 で海面温度を求めが、例えばチャン ネル 5 との組み合せによりこの補正は可能なようである。

いずれにせよ、衛星デー夕を用いることにより、実測が点の調查であるのに対して、冷水塊の存在を面的に捉 えることが出来ることが明らかとなった。

1) 水野信二郎・ 川建和雄 - 三井田恒博: 対馬東水道と周辺海域における海洋観測, 九州大学応用力学研究所所報, 第60号, pp. 445 454, 1984.

2）西日本新聞：黑潮東へ300艺ずれる（新聞記事より），1986.9.

3）中村 充: 海のロマンー海洋開発, Chamber, 1986.1/2, pp. 48〜56.

4) 水産工学研究所：水産工学研究の現況, 1985.4.

5) 上原春男：海洋温度差発電読本，オーム社, pp. 7 11, 1982.7.

6）後藤恵之輔・三井田恒博・水野信二郎・川建和雄: 対馬東水道及び周辺海域における海面温度の遠隔観測, 長崎大学工学部研究報告, 第16巻, 第 27 号, pp. 161 164, 1986.7.

7）日本造船振興財団：人工衛星，J A F S A リモートセンシング資料，No. 1，pp. 38〜43，1981. 